possibility that they may indicate Eskimo influence or perhaps even a former Eskimo habitation of the island. During excavations which revealed ancient Eskimo culture on the long-since deserted island of Punuk, off St. Lawrence in north-western Alaska, Henry B. Collins, of the U.S. National Museum, discovered ruined houses of the historic period which bear close resemblance to the houses of North Rona. There is the same subterranean construction, low walls, carrying a low roof, and an entrance by way of a long narrow tunnel. The chief difference is in the building material, for the Punuk houses are constructed of a framework of driftwood logs and the bones of whales, apparently jaw bones and ribs $^{2}$.

There is no reason why North Rona, lying forty miles north of the Scottish mainland, might not at some early period have been colonised by Eskimos. But there is the other possibility that the peculiar conditions of exposed, wind-swept islands, lacking protective vegetation, may have led to the independent development of this curious type of hut in these distant places. Something of the same kind has been revealed in the excavations supervised by Prof. Gordon Childe at Skara-brae in the Orkney Isles.

Natural History Department, JAMES RITCHIE. University of Aberdeen.

1 NATURE, 133, 399, March 17, 1934.

列 1928, Washington 1929 , p. 148 .

\section{Chromosome Differences in Mice Susceptible and Resistant to Cancer}

Counts of chiasma frequency made at early, mid and late diaphase of spermatogenesis have revealed a significant difference between two strains of mice, one highly susceptible to spontaneous development of mammary carcinoma, the other highly resistant. The strains are respectively $A$ and $C B A$ obtained from Dr. C. C. Little, Roscoe B. Jackson Memorial Laboratory, Bar Harbor, Maine.

The mean number of chiasmata per cell is 28.44 in strain $A$, and $33 \cdot 12$ in strain $C B A$. The difference between them is 4.68 (with a standard error of 0.707 ); the necessary difference for $P=0.01$ is only 1.909 (Fisher, "Statistical Methods for Research Workers", 3rd ed.). The test for significance of the difference in distribution gave $\chi^{2}=54 \cdot 93$, as shown in the accompanying table; the requirement for $P=0.01$ is only $11 \cdot 341$.

\begin{tabular}{|c|c|c|c|c|c|}
\hline & \multicolumn{4}{|c|}{ Number of bivalents } & Total \\
\cline { 2 - 6 } $\begin{array}{c}\text { Number of } \\
\text { chiasmata } \\
\text { per bivalent }\end{array}$ & 1 & 2 & 3 & 4 & bivalents \\
\hline $\begin{array}{c}\text { Strain } A \\
\text { (susceptible) }\end{array}$ & 304 & 181 & 15 & 0 & 500 \\
\hline $\begin{array}{c}\text { Strain } C B A \\
\text { (resistant) }\end{array}$ & 247 & 185 & 61 & 7 & 500 \\
\hline $\begin{array}{c}\text { Total } \\
\text { bivalents }\end{array}$ & 551 & 366 & 76 & 7 & 1,000 \\
\hline$\chi^{2} / m$ & $13 \cdot 15$ & $0 \cdot 09$ & $34 \cdot 69$ & $7 \cdot 00$ & $\chi^{2}=54 \cdot 93$ \\
\hline
\end{tabular}

The data have been obtained from two distinct studies in which different fixatives and slightly different methods of staining were used. Twenty. eight complete nuclei were analysed in the first test and twenty-two in the second. In each case these comprised equal numbers of nuclei at the same stages of meiosis from each strain. They were from seven mice of comparable ages. The results from the two studies were in complete agreement.

These observations were made as a first test of a series of simple related working hypotheses on the mechanism of heritable susceptibility to cancer. The hypotheses are based primarily on the somatic cell mutation theory of cancer, and the discovery of genes and chromosome deficiencies affecting the mechanism of mitosis or meiosis ${ }^{1}$. This first test of chiasma frequency is, of course, entirely indirect in its possible application to the cancer problem; it hinges on the relationship of meiosis to mitosis ${ }^{2}$. Though indirect, the chiasma frequency test is, on the hypotheses formulated, of particular value since it provides a relatively precise quantitative measure of differences between sets of chromosomes; other tests are in progress. Until they are completed anp other strains of mice tested for chiasma frequency, it would be premature to discuss the possible significance of these data for the cancer problem. They are in striking accord with expectation on the basis of the particular hypothesis they were designed to test, but the possibility of an unknown factor other than cancer susceptibility being involved has not yet been eliminated.

Apart altogether from the cancer problem, the results obviously have general cytogenetic significance.

\section{Leonard Huskins. E. Marie Hearne.}

MeGill University, Montreal. March 3.

${ }^{1}$ Huskins, C. L., and Hearne, E. M., J. Roy, Micro. Soc., 53, 109 1933 .

${ }^{2}$ Huskins, C. L., Nature, 132, 62, July 8, 1933.

\section{International Status and Obligations of Science}

IN Nature of February 24 were published letters from Prof. Stark and myself referring to dismissed German scholars and scientists. I could not neglect the opportunity of saying that the Academic Assistance Council (Burlington House, W.1) urgently needs funds. Whether it was Prof. Stark's eloquence or mine I am not sure (perhaps a little of each), but an unknown friend in America has written me referring to this correspondence and enclosing five cheques from members of his family to the amount of 230 dollars, "to be used for furthering this assistance". He hopes to send "a little more".

His generous action will provide for one of our colleagues for several months, but-will Prof. Stark allow me to say ?-many still need help, and there is next year and the year after before a limit to the problem can be seen: and who can tell what may happen elsewhere? This gift represents 0.2 per cent of what is still required for the next two years. Will other readers of NATURE help with the remainder ?

University College,

A. V. HrLL. Gower Street,

London, W.C.1. March 23. 